\title{
EVALUATION ON THE IMPLEMENTATION OF EARLY WARNING SYSTEM FOR DEBRIS FLOW IN MERAPI AREA (CASE STUDY AT BOYONG RIVER)
}

\author{
Ali Cahyadi Achmad \\ Executive of Water Resources Management, Public Works Office of North Maluku Province, Ternate, Indonesia \\ arnalthan@gmail.com
}

\begin{abstract}
Debris flow is one of disasters caused by volcanic activity of Mount Merapi which occurs after volcanic eruption. Eruption produces volcanic and pyroclastic material deposit around the top of the mountain which might collapse downward in the form of debris flow as it is affected by natural event such as high intensity rainfall. Therefore, a research is needed to analyze whether existing forecasting and early warning system are capable to provide information for the people living in hazardous area before the debris flow occur. This research was carried out using field survey, observation and interview method. Data analysis used qualitative descriptive method by making description of actual condition of the researched location general condition and qualitative analysis of telemetry system installed on Mount Merapi. The qualitative analysis of telemetry system covers network, hardware, software, power supply, security system, operation and maintenance, also human resources. Research analysis used primary and secondary data. Research results revealed that mean rainfall intensity above of 60 $\mathrm{mm}$ /hour might trigger debris flow. Early warning should be given at the rainfall intensity level of 50-55 mm/hour, and debris flow time travel from the upstream to the observed location in Pulowatu Village is 45 minute. Based on the analysis of the present forecasting and early warning system, it is known that some of the equipment is not well functioned, so that debris flow cannot be predicted and detected. This is caused by the lack of human resource quality of the officers in operating and maintaining the equipment. Concerning that matter, it is necessary to conduct some improvement to achieve better forecasting and early warning system in order to give information regarding occurrence of debris flow.
\end{abstract}

Keywords: telemetry system, rainfall intensity, information spreading

\section{INTRODUCTION}

The debris flow of Mount Merapi happened because of the collapse of lava dome which consists of volcanic and pyroclastic material due to the high intensity rainfall. To decrease the impact of the debris flow, one of solutions that can be applied is to conduct a non-structural mitigation by developing telemetry system for forecasting and early warning in order to give warning to the residents living in the disasterprone area, before the debris flow occur.

Boyong River is one of the rivers flowing from Mount Merapi. Code River located in the downstream of Boyong River is the river that traverses Yogyakarta City and dense settlement occupies along the riverbank. Based on this condition, a research is needed to analyze whether the installed early warning system can give adequate information and sufficient time to the resident in disaster-prone area before the debris flow occur.

\section{DEBRIS FLOW WARNING SYSTEM}

\subsection{Forecasting and Early Warning System}

The type of equipment that can be used to detect debris flow can be seen in Table 1 .

Table 1. Type of equipment used to detect secondary disaster (debris flow) (Ishikawa \& Yamada, 2004)

\begin{tabular}{|c|c|c|}
\hline No & Equipment type & Function \\
\hline 1 & Rain gauge & To measure rainfall \\
\hline \multirow[t]{2}{*}{2} & Radar rain gauge & $\begin{array}{l}\text { To measure rainfall and } \\
\text { discovere location where } \\
\text { it occurs }\end{array}$ \\
\hline & & $\begin{array}{l}\text { b) Rainfall intensity } \\
\text { spatially }\end{array}$ \\
\hline 3 & Wire sensor & To detect debris flow movement \\
\hline 4 & $\begin{array}{l}\text { Ultrasonic water } \\
\text { level gauge }\end{array}$ & To detect the depth of debris flow \\
\hline 5 & $\begin{array}{l}\text { Current meter } \\
\text { (ultrasonic) }\end{array}$ & $\begin{array}{l}\text { To detect the velocity of debris } \\
\text { flow }\end{array}$ \\
\hline 6 & Vibration sensor & $\begin{array}{l}\text { To find the existence of debris } \\
\text { flow }\end{array}$ \\
\hline 7 & Video camera & $\begin{array}{l}\text { To monitor changes and damages } \\
\text { caused by debris flow }\end{array}$ \\
\hline
\end{tabular}




\subsection{Debris Flow Forecasting Analysis}

Ministry of Land Infrastructure and Transportation (MLIT) of Japan has developed analytical method for debris flow forecast by using Working Rainfall data for 7 (seven) days before the debris flow events. The antecedent rainfall (working rainfall) can be calculated by the following formula

$R W A=\sum_{i=1}^{i=7} a_{i} \times d_{i}$

where $R W A$ is antecedent rainfall (working rainfall) $(\mathrm{mm}), \alpha$ is reduction cofficient which is $0.5^{i / T}, T$ is 0.5 (day), and $i$ is day (National Institute for Land and Infrastructure Management, Ministry of Land, Infrastructure and Transport (MLIT), 2001).

\subsection{Travel Time}

Travel time of debris flow was calculated to find the time that debris flow needs to reach the observed locations in which the resident settlement and sand mining located, by using the following formula (Rhiza formula):

$t=\frac{L}{V}$

$V=72\left(\frac{H}{L}\right)^{0.6}$

where $t$ is travel time (hour), $L$ is river length (km), $V$ is the flow velocity ( $\mathrm{km} /$ hour), and $H$ is the height difference from the initial point to the observed point $(\mathrm{km})$.

\section{RESEARCH METHOD}

\subsection{Research Location}

The research was located on Boyong River, Sleman Regency, Yogyakarta Province where a couple of forecast and early warning telemetry stations installed, as shown in Figure 1.

\subsection{Research Implementation}

The research implementation started with collecting the secondary data of forecasting and early warning system, such as telemetry network map, telemetry system data, rainfall data, and water level gauge data. Primary data was obtained from the field observation, interview with sources, and questionnaire distribution to the sand miners/residents that live in the disasterprone area. After the entire data was collected, the next step was to conduct qualitative analysis which comprised of telemetry system, hardware, software, power supply, security system, the operation, and the maintenance of the human resources, in order to gain short-term development perspective and long-term forecasting and early warning system of the debris flow occurrence in Mount Merapi area, particularly Boyong River.

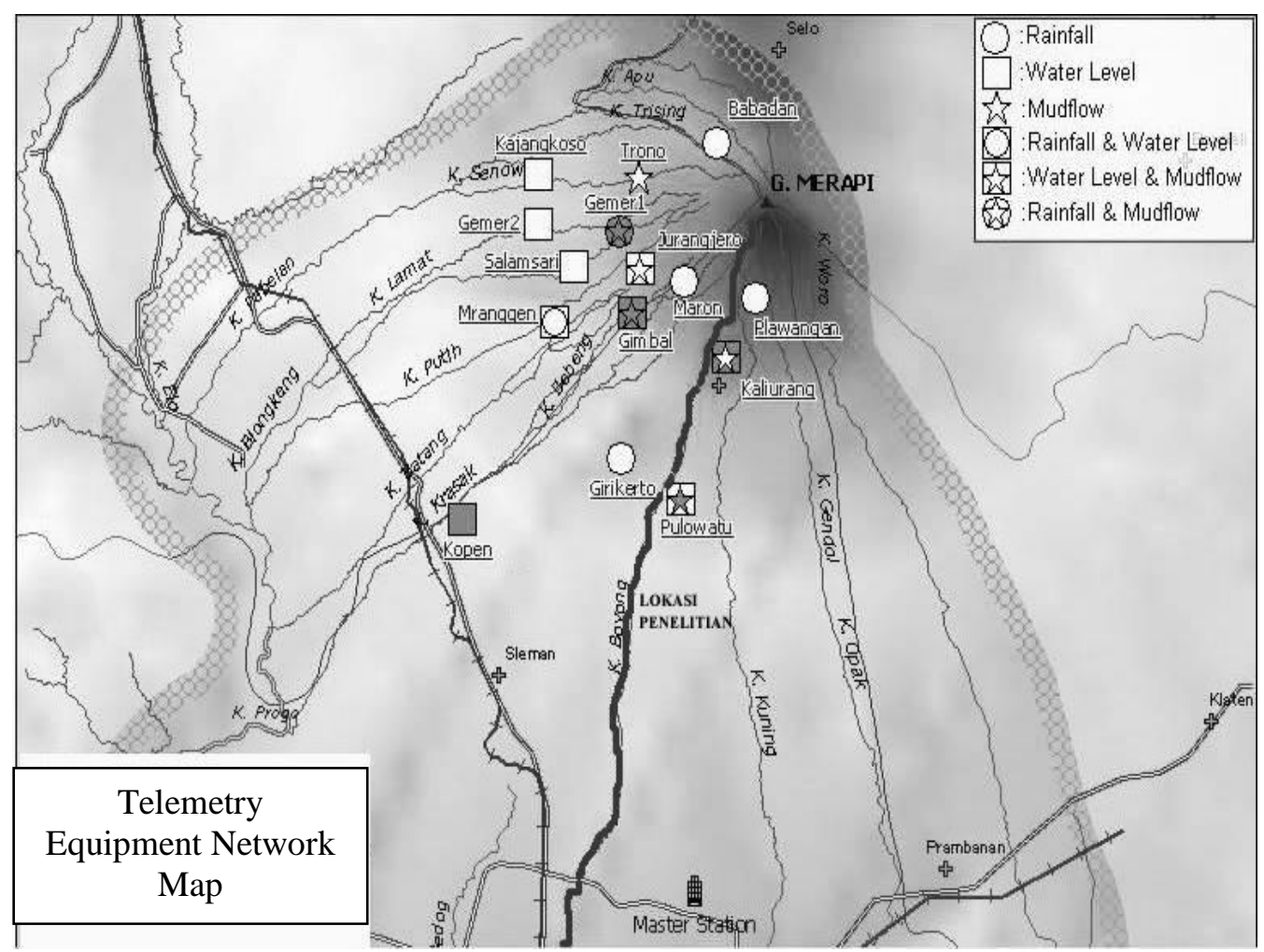

Figure 1. Telemetry equipment network map in Mount Merapi area. 


\section{RESULT AND DISCUSSION}

\subsection{Institutions related to Lahar Disaster Management in Mount Merapi}

The early warning and forecasting system in Mount Merapi basically refers to the early warning and forecasting system as seen in Figure 2. For the disaster management in the Sleman Regency area, the Regent of Sleman established the Disaster Management Implementation Unit (Satlak PB) that directly chaired by the Regent himself and assisted by vice chairman, secretary, treasurer, and sections. According to the information flow related to the forecasting and early warning system in Mount Merapi, the Sabo Office gives information to Satlak $P B$, which directly supervises some Disaster Management Operation Unit led by the head of the sub-district. The Disaster Management Operation Unit coordinates with
Disaster Management Task Unit on village level chaired by each head of village in order to give direct information to the residents that live in disaster-prone areas.

\subsection{Telemetry System Equipment for Debris Flow Forecasting and Early Warning}

The study result on telemetry equipment for debris flow forecasting and early warning can be seen from Table 2 thru Table 5.

\subsection{Evaluation on Debris Flow Forecasting System}

The debris flow forecasting is done by analyzing hourly rainfall data from 1995 to 2003 and water level gauge data (AWLR). As the result, the estimated rainfall amount that can induce debris flow has average value more than $60 \mathrm{~mm} / \mathrm{hour}$, and cumulative amount above $150 \mathrm{~mm} /$ day.

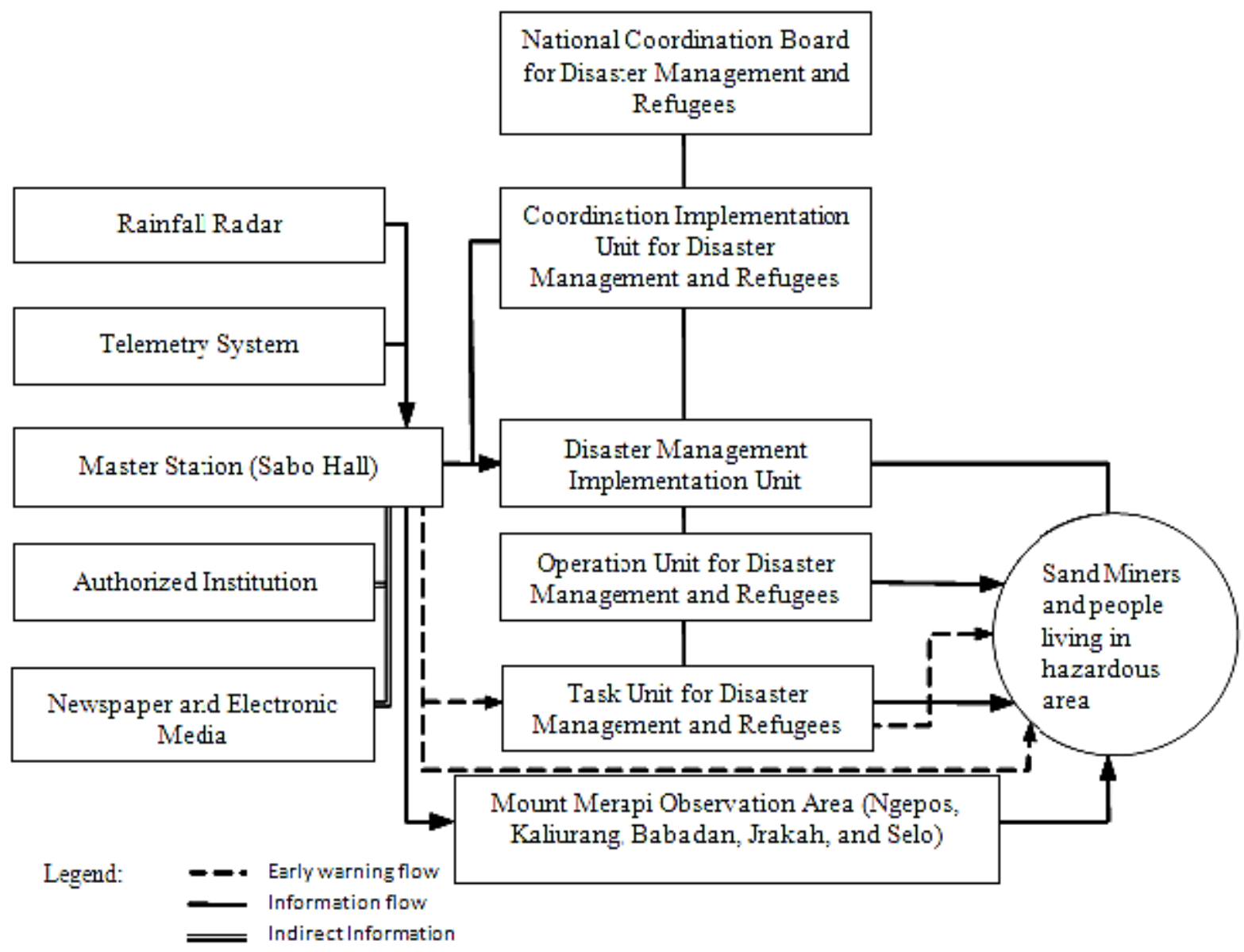

Figure 2. Scheme of Forecasting and Early Warning System on Mount Merapi Area. 
Table 2. Plawangan Automatic Rain Gauge Station (telemetry system)

\begin{tabular}{|c|c|c|c|c|c|c|c|}
\hline \multirow{2}{*}{$\begin{array}{l}\text { Equipment } \\
\text { Name }\end{array}$} & \multicolumn{2}{|l|}{ Installation } & \multirow[t]{2}{*}{ Condition } & \multicolumn{2}{|c|}{ Problem } & \multirow{2}{*}{\multicolumn{2}{|c|}{ Improvement }} \\
\hline & Location & Year & & & & & \\
\hline \multirow[t]{3}{*}{$\begin{array}{l}\text { Rain Gauge } \\
\text { Station }\end{array}$} & Plawangan & 1984 & $\begin{array}{l}\text { Well } \\
\text { functioned }\end{array}$ & a) & $\begin{array}{l}\text { Volcanic ashes that resulted from } \\
\text { Mount Merapi activity caused } \\
\text { rotten on the rain gauge bucket } \\
\text { and clogged the rain water filter, } \\
\text { hence made the measured } \\
\text { rainfall data became less } \\
\text { accurate. }\end{array}$ & a) & $\begin{array}{l}\text { Duty officer conducts regular } \\
\text { cleaning on the filter of rain } \\
\text { gauge bucket, furthermore the } \\
\text { coating of anti-rust paint should } \\
\text { be conducted on certain station } \\
\text { parts that close to Mount Merapi } \\
\text { peak. }\end{array}$ \\
\hline & & & & b) & $\begin{array}{l}\text { Connection system is still } \\
\text { analogue, hence it often caused } \\
\text { troubles and the data delivery } \\
\text { process needs more time. }\end{array}$ & b) & $\begin{array}{l}\text { Connection system needs digital } \\
\text { modification, in order to speed } \\
\text { up the data delivery process to } \\
\text { master station, and also to }\end{array}$ \\
\hline & & & & c) & $\begin{array}{l}\text { The position of the station is far } \\
\text { from the resident settlement so } \\
\text { that the operational and } \\
\text { maintenance of the equipment is } \\
\text { not optimal. }\end{array}$ & c) & $\begin{array}{l}\text { prevent easy global intervention. } \\
\text { Post/equipment guardhouse for } \\
\text { the equipment guard officer is } \\
\text { necessary to build. The number } \\
\text { of the officers are needs to add. }\end{array}$ \\
\hline
\end{tabular}

Table 3. Kaliurang Ultrasonic Water Level Gauge Measurement Station, Wire Sensor, and Vibration Sensor

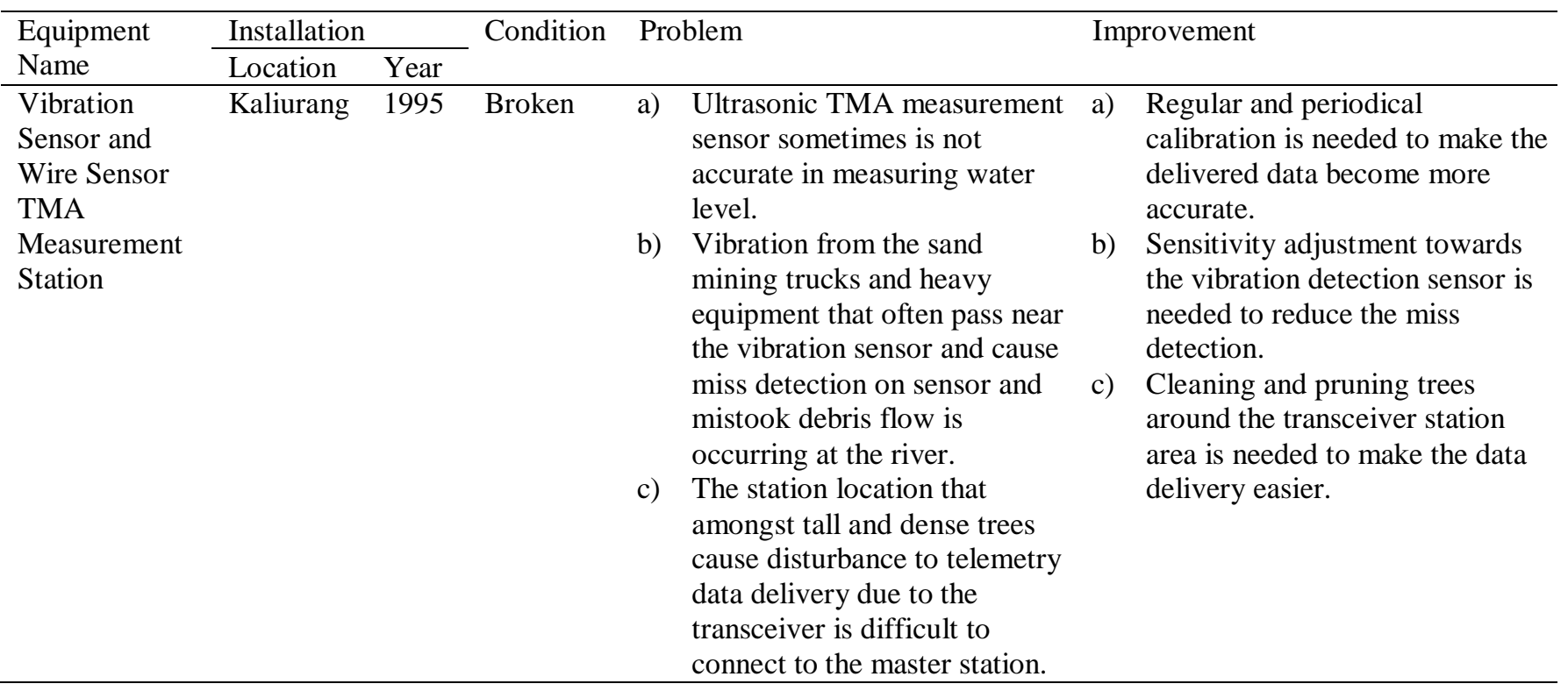

Table 4.Girikerto Automatic Rainfall Measurement Station (telemetry system)

\begin{tabular}{|c|c|c|c|c|c|}
\hline \multirow{2}{*}{$\begin{array}{l}\text { Equipment } \\
\text { Name }\end{array}$} & \multicolumn{2}{|c|}{ Installation } & \multirow[t]{2}{*}{ Condition } & \multirow[t]{2}{*}{ Problem } & \multirow[t]{2}{*}{ Improvement } \\
\hline & Location & Year & & & \\
\hline $\begin{array}{l}\text { Rainfall } \\
\text { Measurement } \\
\text { Station }\end{array}$ & Girikerto & 1985 & $\begin{array}{l}\text { Well } \\
\text { Functioned }\end{array}$ & $\begin{array}{l}\text { Connection system applies } \\
\text { analogue, hence disturbances are } \\
\text { often encountered and the data } \\
\text { delivery process need longer time. }\end{array}$ & $\begin{array}{l}\text { Modifying the connection system } \\
\text { into digital in order to speed up the } \\
\text { data delivery process to master } \\
\text { station, and also to prevent easy } \\
\text { global intervention. }\end{array}$ \\
\hline
\end{tabular}

Table 5.Pulowatu Ultrasonic Water Level Gauge Measurement Station and Wire Sensor

\begin{tabular}{|c|c|c|c|c|c|}
\hline \multirow{2}{*}{$\begin{array}{l}\text { Equipment } \\
\text { Name }\end{array}$} & \multicolumn{2}{|c|}{ Installation } & \multirow[t]{2}{*}{ Condition } & \multirow[t]{2}{*}{ Problem } & \multirow[t]{2}{*}{ Improvement } \\
\hline & Location & Year & & & \\
\hline $\begin{array}{l}\text { Wire Sensor } \\
\text { and TMA } \\
\text { Measurement } \\
\text { Station }\end{array}$ & Pulowatu & 1995 & $\begin{array}{l}\text { Well } \\
\text { Functioned }\end{array}$ & $\begin{array}{l}\text { The water level gauge data sent } \\
\text { by the station is sometimes not } \\
\text { accurate. }\end{array}$ & $\begin{array}{l}\text { Need regular and periodical } \\
\text { calibration on the equipment in } \\
\text { order to stop error on early warning } \\
\text { and information distribution. }\end{array}$ \\
\hline
\end{tabular}


Soil saturation can also be the trigger factor for the debris flow, since even though the rainfall amount at the debris flow event was less than $60 \mathrm{~mm} / \mathrm{hour}$, and such high intensity rainfall happened 3 (three) or 4 (four) days in a row before the occurrence, the soil saturation may increase and induce the debris flow. This point may cause some debris flow to be positioned under the critical line which can be seen in Figure 3 and Figure 4.

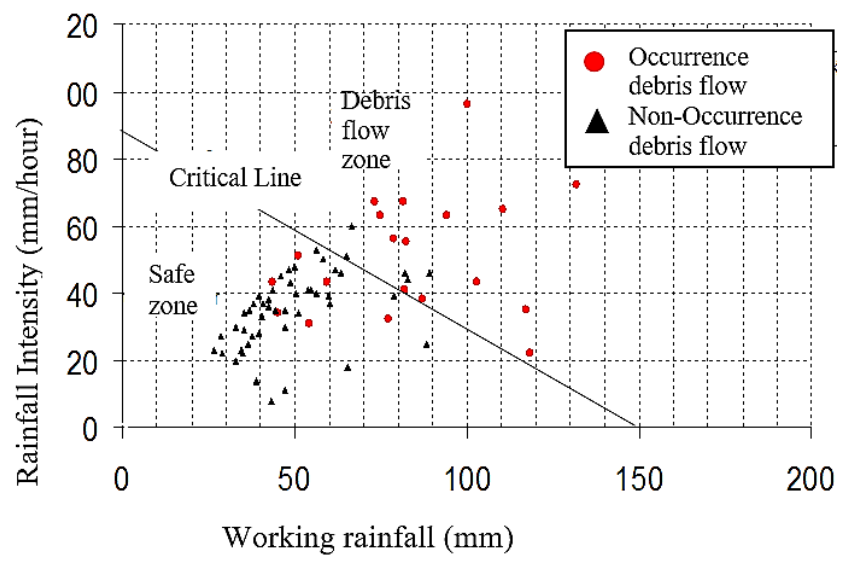

Figure 3. Prediction of debris flow event with 7 (seven) days working rainfall.

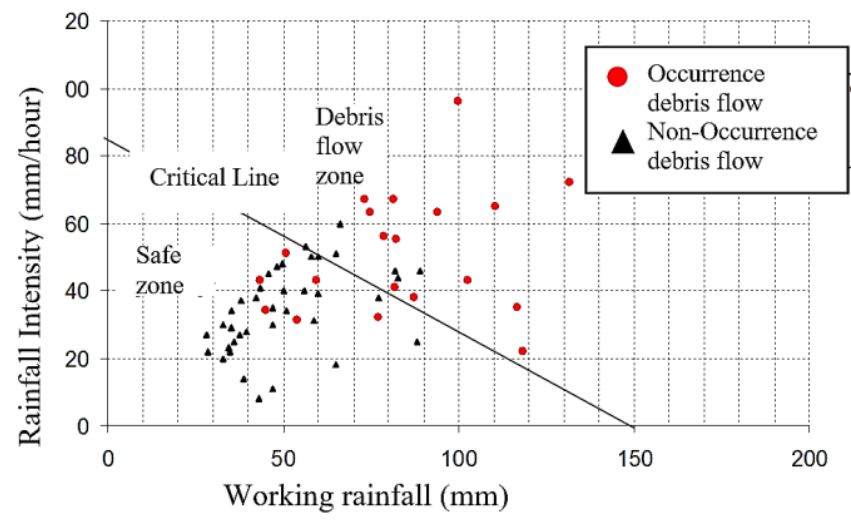

Figure 4. Prediction of the debris flow with 4 (four) days working rainfall.

Table 6. Travel time calculation in Boyong River
From the debris flow forecasting graphs, it can be seen that early warning on debris flow ought to be delivered when the rainfall reach level of $50 \mathrm{~mm} /$ hour to $55 \mathrm{~mm} /$ hour. In the system of debris flow forecasting information delivery, the estimated travel time of debris flow to reach the observed points which are the dense settlement along the Boyong River side on Pulowatu (Location 2) and the sand mining activity area in Boyong River upstream BOD6 (Location 2) should be conducted.

Based on the travel time of the debris flow (see Table 6 ), the time needed for the debris flow to reach Location 1 and Location 2 was 45 minute. The forecasting and early warning system for the debris flow needs to be optimized since there were numbers of equipment from the system that is broken and not well functioned.This condition causes the master station could not predict and monitor the debris flow occurrence.

Estimation was analysed also by considering working rainfall for 4 (four) days before the debris flow event. Though it is rare to have rain fall for 7 (seven) days in a row in Mount Merapi, it is mostly happen for about 4 (four) consecutive days. The hydrology model calculation result for debris flow forecasting with 7 (seven) days working rainfall and 4 (four) days working rainfall can be seen in Figure 3 and Figure 4.

\subsection{Evaluation Result on Early Warning System}

The early warning system on Mount Merapi area is basically refers to the early warning system scheme, as seen in Figure 2. According to the scheme, Sabo Office as the master station receives dangerous signal/data from telemetry stations spread over Mount Merapi area and distributes the information to authorized institutions, in order to deliver early warning to residents who live in disaster-prone areas.

\begin{tabular}{|c|c|c|c|c|c|c|c|c|}
\hline \multirow{2}{*}{$\begin{array}{l}\text { Cross } \\
\text { Section }\end{array}$} & \multirow[t]{2}{*}{ Name } & \multirow[t]{2}{*}{$\mathrm{L}(\mathrm{m})$} & \multicolumn{3}{|c|}{ River base elevation } & \multicolumn{2}{|l|}{ Travel time $(\mathrm{t})$} & \multirow[t]{2}{*}{ Remarks } \\
\hline & & & $\begin{array}{l}\text { Initial } \\
\text { point (m) }\end{array}$ & $\begin{array}{l}\text { Observed } \\
\text { point }(\mathrm{m})\end{array}$ & $\mathrm{H}(\mathrm{m})$ & $\begin{array}{l}\text { Between section } \\
\text { (minutes) }\end{array}$ & $\begin{array}{l}\text { Cumulative } \\
\text { (minutes) }\end{array}$ & \\
\hline $0-1$ & Peak - BOD7 & 6600 & 2928 & 876 & 2100 & 11.00 & 11.00 & \\
\hline $1-2$ & BOD7 - BOD6 & 1170 & 876 & 760 & 116 & 4.20 & 15.20 & Location 1 \\
\hline $2-3$ & BOD6 - BOD5 & 590 & 760 & 719 & 41 & 2.45 & 17.65 & \\
\hline $3-4$ & BOD5 - BOD4 & 923 & 719 & 665 & 54 & 4.20 & 21.85 & \\
\hline $4-5$ & BOD4 - BOD3 & 830 & 665 & 610 & 55 & 3.70 & 25.55 & \\
\hline $5-6$ & BOD3 - BOD2 & 1024 & 610 & 563 & 47 & 5.20 & 30.75 & \\
\hline $6-7$ & BOD2 - BOD1 & 2324 & 563 & 470 & 93 & 13.80 & 44.55 & Location 2 \\
\hline
\end{tabular}


Table 7. Problem and Proposal for Improvement on Early Warning System

\begin{tabular}{cll}
\hline No & Problem & Proposed Improvement \\
\hline 1 & $\begin{array}{l}\text { Disaster Management Working Unit (Satgas PB) does } \\
\text { not have post/officer in the mining location, also the } \\
\text { number of miners and resident that have radio } \\
\text { communication (walkie-talkie) is still limited. }\end{array}$ & $\begin{array}{l}\text { Establish guard post for Disaster Management Working } \\
\text { Unit equipped with radio communication on each mining } \\
\text { location which is far from resident settlement. }\end{array}$ \\
$\begin{array}{l}\text { A lot of sand miners and truck drivers have not } \\
\text { understood the mechanism of debris flow occurrence } \\
\text { and its risks. }\end{array}$ & $\begin{array}{l}\text { Enhance the socialization on the understanding of debris } \\
\text { flow mechanism and the risk and caused damage. }\end{array}$ \\
$\begin{array}{l}\text { Early warning alarm in form of siren or bamboo slit } \\
\text { drum (kentongan) is less audible on the mining area } \\
\text { located far from the settlement. }\end{array}$ & $\begin{array}{l}\text { To install repeater on certain location for inceasing the } \\
\text { siren sound scope. }\end{array}$ \\
\hline
\end{tabular}

The largest debris flow ever recorded in Boyong River was happened in $5^{\text {th }}$ December 1996 led to 14 unit of sand mining trucks drown and stuck in the debris flow stream. From results of evaluation and review of the $5^{\text {th }}$ December 1996, there were some problem and improvement proposal on the early warning system which were listed in Table 7.

\subsection{Evaluation Result on Forecasting and Early Warning System Development}

The suggestion for short-term development is by conducting improvement on the telemetry station equipment as noted from Table 2 thru Table 5. Furthermore, a few other things also need to be conduct, as follows:

a) Skill building of the equipment guard officer in the terms of operational and maintenance of the equipment. Training should be held for the telemetry station equipment guard officer spread around some locations, because observation result showed that most of the equipment guard officers do not understand the equipment function and procedure.

b) Socialization on early warning system for the miners/residents. Socialization should be held for the miners/residents who live in the disaster-prone area, for there are still a lot of the miners/residents have not understood the mechanism of the debris flow and the damages.

From the result of the review and evaluation, the suggestion for the long-term development of forecasting and early warning system is to install the latest rain gauge radar since it has some advantages, i.e. (Sukatja, 2004):

a) It can monitor rainfall that still heading to the soil surface.

b) It has wide observation area.

c) It can monitor the rainfall intensity distribution and its changes continuously on real time.

d) By adding the Plan Position Display (PPD) that has function as a real time monitor, it can monitor cloudy weather and rainfall intensity under 5 $\mathrm{mm} /$ hour.

\section{CONCLUSIONS}

The forecasting and early warning system in Mount Merapi area, particularly the Boyong River, still could not deliver early information to the resident that live in disaster-prone area optimally, because some of the telemetry equipment that supports the forecasting and early warning system are not well functioned (broken). From the review and the evaluation, those are caused by low maintenance on the telemetry equipment as the consquence of the limited budget on operational and maintenance, also the low quality of human resources, especially the equipment guard officer that in charge on the equipment operational and maintenance.

The rainfall intensity that can induce debris flow in Mount Merapi area, particularly Boyong River has average value more than $60 \mathrm{~mm} /$ hour, or cumulative value more than $150 \mathrm{~mm} /$ day. Based on this, the information then should be delivered by Sabo Hall master station to Satlak $P B$ when the rainfall intensity reaches the level of 50 to $55 \mathrm{~mm} /$ hour.

From the calculation of debris flow travel time, it was found that the time the debris flow needed to reach the observed location, Pulowatu village, was approximately 45 minutes. The present forecasting and early warning system is necessary to be optimized since there were still broken supporting equipment.

\section{REFERENCES}

Ishikawa, Y. \& Yamada, T., 2004. Monitoring and Acquisition System, Yogyakarta.

National Institute for Land and Infrastructure Management, Ministry of Land, Infrastructure and Transport (MLIT), 2001. Method for Setting Standard Rainfall for Warning and Evacuation From Sediment Disasters, Jakarta. 
Sukatja, 2004. Memperkirakan Banjir dengan Radar Pengukur Hujan [Flood Prediction using Radar]. Surabaya, ITS. 
[this page intentionally left blank] 